\title{
Forskydninger: Mellem svar og ikke-svar
}

\section{En retorisk analyse af Lars Løkke Rasmussens svar på tirsdagspressemøderne}

\author{
AF JONAS GABRIELSEN, HEIDI JØNCH-CLAUSEN \\ OG CHRISTINA PONTOPPIDAN
}

\begin{abstract}
At politikere søger at undvige journalisters spørgsmål, er velkendt. Måden, det gøres på, varierer imidlertid meget. I denne artikel argumenteres der for det hensigtsmæssige i at sondre mellem afvisninger, hvor et svar helt nægtes besvaret, og forskydninger, hvor præmissen for journalistens svar ændres i svaret. For at afdække, hvad en forskydning mere præcist er, har forfatterne nærlæst 14 af tidligere statsminister Lars Løkke Rasmussens tirsdagspressemøder. Herudfra opstiller de en typologi over Løkkes tre hyppigste måder at forskyde et spørgsmål på: tidsforskydning, aktørforskydning og niveauforskydning.
\end{abstract}

\section{Indledning}

Anders Fogh Rasmussen (V) (statsminister mellem 2001-2009) er blevet fremhævet som den politiker, der for alvor bragte strategisk kommunikation til dansk politik. Med ham i spidsen var Venstre blandt de første til at benytte sig af fokusgrupper, mærkesager og talepunkter (faste vendinger, der gentages igen og igen) (Jønsson og Larsen 2002; Qvortrup 2002). Skal man tro landets politiske journalister, blev den journalistiske udfordring imidlertid ikke mindre, højst anderledes, efter at Lars Løkke Rasmussen (V) (herefter Løkke) overtog statsministerposten.

Særligt de ugentlige tirsdagspressemøder gav i løbet af hans 
tid som statsminister anledning til frustration og kritik fra journalistisk hold. Løkke blev kritiseret for manglende dialog, som blandt andet kom til udtryk i meget lange svar, der slørede fokus, ligesom han blev kritiseret for at genfortolke eller glide af på journalisternes spørgsmål (Hesselager 2009).

Den journalistiske frustration synes således ikke så meget at gå på, at Løkke afviste at svare på spørgsmål, som at han svarede på noget andet end det, han blev spurgt om. Hverken de lange svar eller omfortolkningen af de stillede spørgsmål indebar nemlig en kontant afvisning af journalistens spørgsmål - som vi kender det fra Anders Fogh Rasmussens velkendte "Der er ikke noget at komme efter". Hvor udfordringen i forhold til Anders Fogh Rasmussen var hans knappe stil og de planlagte, præcise formuleringer, var udfordringen i forhold til Løkke snarere hans ordrige stil og det, at hans svar ofte blev drejet i forhold til det stillede spørgsmål.

Det er netop den form for svar, som indebærer en drejning af journalistens spørgsmål, der er denne artikels fokus. Med en samlebetegnelse kalder vi fænomenet for forskydninger og kategoriserer overordnet en forskydning som en type svar, der befinder sig mellem svar og ikke-svar.

For at indkredse, hvad en forskydning mere præcist er, og for at vise, hvordan forskydninger fungerer i praksis, har vi nærlæst 14 af Løkkes tirsdagspressemøder. Med udgangspunkt i dette materiale opstiller vi en typologi over tre former for forskydning, der er typiske for Løkke, nemlig tidsforskydning, aktørforskydning og niveauforskydning. Før vi udfolder typologien, skal vi dog først adressere det bagvedliggende teoretiske rationale bag en forskydning.

\section{Undvigelsens dobbelthed: At afvise eller forskyde}

For at forstå forskydningens natur er det formålstjenstligt at anlægge en analytisk skelnen mellem spørgsmålsafvisninger og spørgsmålsforskydninger. En sondring, der, som vi skal se, kan genfindes i litteraturen, om end både begreber og demarkationskriterier varierer.

Afvisninger af journalistiske spørgsmål kan antage en række forskellige former, hvor den mest kontante form er den velkendte 
formulering: 'Ingen kommentarer!' Afvisningen kan dog også komme til udtryk ved, at svareren henviser til, at han ikke er den rette til at svare, at tiden ikke er moden til at besvare spørgsmålet, eller at spørgsmålet er upassende eller overflødigt. Det er svar af typen: 'Det er jeg ikke den rette til at udtale mig om', 'Lad os vende tilbage til det, når kommissionen har afsluttet sit arbejde', 'Det vil jeg ikke svare på, så laenge sagen kører', 'Jeg forholder mig ikke til personsager', 'Det har jeg jo lige svaret på.' Med svar som disse søger svareren på forskellig vis at retfærdiggøre, at han ikke svarer.

Afvisninger er, ligesom de er relativt lette at identificere i praksis, også lette at genfinde i den teoretiske litteratur. Christian Kock kalder eksempelvis manøvren for affejninger og kategoriserer dem som en form for ikke-svar (Kock, 2011, s. 136). Hos Steven Clayman og John Heritage betegnes afvisninger som the negative dimension. Det dækker over tre forskellige måder, hvorpå et spørgsmål kan afvises i et interview: Interviewpersonen kan nægte at svare, han kan svare mangelfuldt, eller han kan nøjes med at svare "ja" eller "nej" på et spørgsmål, der åbenlyst kalder på uddybning (Clayman og Heritage, 2002, s. 250). Endelig sondrer Peter Bull og Kate Mayer mellem svar, ikke-svar og implicerende svar. Under kategorien ikke-svar, som er den kategori, der i den aktuelle sammenhæng interesserer os, opregner de en lang række måder, hvorpå svar kan afvises: Man kan ignorere spørgsmålet, stille sig uforstående over for spørgsmålet, angribe spørgsmålet, angribe intervieweren, nægte at svare, komme med et mangelfuldt svar, gentage tidligere svar eller hævde, at man allerede har svaret (Bull og Mayer, 2002, s. 662). Trods de begrebslige forskelle synes det således at være en kollektiv observation, at en måde, hvorpå man kommer uden om kritiske spørgsmål, er ved at nægte at gå ind i dem - altså afvise dem.

Ud over at afvise journalistens kritiske spørgsmål kan svareren imødegå et journalistisk spørgsmål ved at forskyde det. Her indvilliger svareren i at besvare journalistens spørgsmål, men ændrer i sit svar mere eller mindre ubemærket spørgsmålets optik. Det kan være ved at forskyde et fremtidsrettet spørgsmål (Hvad vil I gøre ved ... ?) til at være et spørgsmål om, hvad der er gjort i fortiden (Det, vi har gjort, er ...), eller ved at forskyde et realpolitisk spørgsmål (Hvordan forholder I jer til sagen om... ?) 
til at være et ideologisk spørgsmål (I partiet X arbejder vi altid for, $a t . .$.$) . Det karakteristiske ved en forskydning er således, at sva-$ reren fastholder spørgsmålets emne, men ændrer det perspektiv eller den promis, som lå til grund for journalistens spørgsmål. En forskydning er dermed hverken en afvisning af det stillede spørgsmål eller en fuldstændig besvarelse af det, men et svar, der ligger mellem disse yderpunkter. Journalistens spørgsmål imødekommes, men journalistens intention med spørgsmålet ignoreres.

Også det, vi her kalder forskydninger, er behandlet i litteraturen - omend diversiteten her synes større end i tilfældet med afvisningen. Kock opererer eksempelvis med to strategier, der kan kategoriseres som forskydninger, idet han skelner mellem fortielse og fordrejning. Fortielsen består i, "at man helt lader være med at komme ind på det plagsomme punkt, som den anden har bragt op", mens fordrejningen "indebærer, at man giver en form for svar - men desværre på en forvansket udgave af det, der blev sagt.” (Kock, 2011, s. 119). På samme måde opererer Clayman og Heritage med to manøvrer, der begge kan kaldes forskydninger: Man kan både svare på noget andet, end spørgsmålet lægger op til, eller vælge kun at besvare dele af spørgsmålet (Clayman og Heritage, 2002, s. 254). Hos Bull og Mayer er det først og fremmest kategorien "To make a political point”, der kan udlægges som en form for forskydning, idet svareren her løfter sagen fra et konkret til et principielt niveau.

Afvisningen og forskydningen tjener altså overordnet betragtet det samme formål: at undvige journalistens spørgsmål. Den analytiske skelnen mellem de to undvigestrategier tillader os imidlertid at identificere nogle afgørende forskelle i måden, hvorpå undvigelsen manifesterer sig: Hvor afvisningen er en måde at undgå journalistens spørgsmål på, er forskydningen en måde at omgå journalistens spørgsmål på; og hvor afvisningen er en åbenlys og defensiv manøvre, er forskydningen en mere skjult og offensiv manøvre. Vi skal nedenfor kaste yderligere lys over forskydningens rationale via en af retorikkens ældste og mest centrale ideer, nemlig den tanke, at selv en svag sag kan styrkes ved at ændre perspektivet. 


\section{Forskydningens kunst: at se sagen fra et favorabelt 'sted'}

Med introduktionen af begrebet forskydning stiller vi os på skuldrene af den klassiske retoriske lære om topik. Ordet 'topik' er afledt af det græske ord 'topos', der direkte oversat betyder 'sted', men som uden væsentligt tab af betydning kan oversættes til betragtningssted eller perspektiv. Med topikken har man fra retorisk hold forsøgt at systematisere den indsigt, at enhver sag kan betragtes fra en række forskellige 'steder', der hver belyser bestemte, mere eller mindre favorable sider af sagen. At tænke topisk er med andre ord at lede efter det perspektiv, der tillader en at fremdrage de stærkeste sider af den sag, man vil forsvare. Heri ligger den centrale indsigt, at det er for snævert alene at forholde sig til en sags faktuelle niveau. Hvilke fakta der er synlige, er nemlig afhængigt af, hvilket perspektiv der er blevet anlagt på sagen, hvorfor en undersøgelse af sagens fakta altid må suppleres med en undersøgelse af, hvilket perspektiv der er blevet anlagt på sagen (Gabrielsen 2006, 2008; Pontoppidan \& Gabrielsen 2010).

Det topiske blik - perspektivafdækningen - er det centrale i en forskydning. Når man forskyder et spørgsmål, bearbejder man ikke de fakta, der spørges til, ved eksempelvis at afvise dem, minimere dem eller gøre dem positive. Med en forskydning ændrer man derimod sagens perspektiv, så alternative og mere positive fakta træder frem. Man ændrer altså ikke fakta, men det anlagte blik på sagens fakta.

Vi trækker imidlertid ikke kun på den topiske grundtanke, men også på det topiske forsøg på at systematisere perspektivudvælgelsen. Frem for at sagsperspektiverne overvejes intuitivt og tilfældigt, kan processen styrkes ved, at man katalogiserer de mest gængse perspektiver i en given kontekst. Man får på denne måde en række forskellige perspektiver på hånden, der kan bruges som pejlemærker i forhold til nye sager (Pontoppidan, Gabrielsen \& Jønch-Clausen 2010; Gabrielsen \& Just 2009).

Det er også i denne forståelsesramme, at det følgende katalog over Løkkes typiske forskydninger må ses. Det er åbenlyst lettere at opdage konkrete forskydninger, hvis man kender de forskydninger, der normalt gøres brug af i en specifik kontekst - i dette tilfælde de ugentlige tirsdagspressemøder. Kataloget over Løkkes typiske forskydninger tjener således det praktiske journalistiske 
formål at afsløre, når Løkke omfortolker et spørgsmål.

\section{Lars Løkke Rasmussens tirsdagspressemøder}

Vi har som nævnt i indledningen nærlæst 14 af Løkkes tirsdagspressemøder. Mere præcist pressemøderne afholdt i perioden fra den 21. april 2009, da Løkke holdt sit første tirsdagspressemøde som landets statsminister, til og med den 9. februar 2010. Der er tale om et relativt omfattende materiale, og det er derfor vigtigt at pointere, at vi har læst det selektivt. Vores mål har ikke været at lave en fyldestgørende analyse af Løkkes formåen som respondent på tirsdagspressemøderne. Målet har udelukkende været at katalogisere de forskellige former for forskydning, han gør brug af i sine svar til de fremmødte journalister. Dette kan give det fejlagtige indtryk, at Løkke forskyder stort set alle de spørgsmål, han stilles. Dette er dog ikke tilfældet. På mange spørgsmål svarer han fyldestgørende og uden at ændre journalistens perspektiv.

Det skal ligeledes nævnes, at vi ikke foretager en vurdering af, hvorvidt de forskellige forskydninger er legitime eller ej. Formålet med analysen er at indkredse, hvad en forskydning er, og på det operationelle niveau at sætte journalisten i stand til at gennemskue og reagere på (Løkkes) forskydninger - ikke lægge grunden for normative vurderinger. Af samme grund forsøger vi at undlade at forholde os til, hvorvidt forskydningerne fra Løkkes side er intenderede eller ej.

Sigtet med analysen er først og fremmest at udfolde forskydningens rationale samt at vise, hvordan dette rationale kan appliceres på et konkret materiale. Analysen er derfor kvalitativ, og vi foretager ikke optællinger af de enkelte forskydningers forekomst. Fremgangsmåden er både deduktiv og induktiv: Deduktiv, fordi den ovenfor skitserede topiske tankemåde har styret vores læsning af materialet; induktiv, fordi forskydningskategorierne er abstraheret fra materialet. De tre former for forskydning, vi opregner: tidsforskydning, aktørforskydning og niveauforskydning, er således produkter af vores læsning og systematisering af materialet, ligesom de tekstreferencer, vi supplerer med i noteform, er tilføjet, efter at kategorierne tog form. 


\section{Tidsforskydning: 'Det ligger mig på sinde, at vi fremadrettet fører en fornuftig økonomisk politik'}

På samme måde som tid er en relativ størrelse i fysikken, kan tid benyttes til at relativere et journalistisk spørgsmål. Tid er med andre ord et muligt 'sted' at forankre en forskydning, forstået på den måde at journalistens spørgsmål kan manipuleres ved at ændre tidsperspektivet. Den første kategori af forskydninger kalder vi derfor for 'tidsforskydning'.

Vi finder i det studerede materiale flere eksempler på svar, hvor Løkke forskyder journalistens tidsperspektiv. Det kan være forskydninger fra fortid til nutid, hvor Løkke besvarer et kritisk spørgsmål vedrørende problematiske handlinger i fortiden med en redegørelse for, hvad man gør ved problemet her og $n u$. Eller det kan være en forskydning fra nutid til fortid, hvor Løkke besvarer et kritisk spørgsmål om en aktuel sag med henvisning til, hvad regeringen tidligere har gjort i sagen. Vi finder også eksempler på forskydninger fra nutid til fremtid, hvor Løkke besvarer et kritisk spørgsmål om et påtrængende problem ved at rette fokus mod, hvad man fremover agter at gøre ved problemet. Det sammenbindende princip er, at Løkkes svar implicerer en ændring af det tidsperspektiv, der ligger til grund for journalistens spørgsmål.

Et illustrativt eksempel på en tidsforskydning finder vi i pressemødet fra den 1. december 2009, da Løkke i sit svar foretager en forskydning fra fortid til fremtid. Vi har i dette og de følgende eksempler fremhævet henholdsvis journalistens tidsperspektiv og eksempler på Løkkes tidsforskydning med kursiv:

Spørger: Regeringen bruger jo ... henviser jo ofte til Nationalbanken, når den siger, at det er klogt at gøre sådan og sådan - eller undlade at gøre sådan og sådan. I går, der holdt nationalbankdirektøren en tale, hvor han kritiserede regeringens økonomiske politik, der er ført mellem 2004 og 2007. Og han sagde ... i hvert fald - det var det, der var meningen, at den har været alt for løssluppen. I skulle have strammet op lang tid før. Og det hele har udviklet sig til en boble. Jeg forventer ikke, at du siger, at du er enig med nationalbankdirektøren. Men kan du sige, hvorfor han har uret? 
Statsministeren: Jeg synes, det er interessant, at du både er i stand til at altså ikke bare at referere nationalbankdirektøren, men også oversætte, hvad det var, han mente - og så i øvrigt foregribe, hvad jeg vil svare. Så behøver jeg jo slet ikke at være til stede. Jeg kan bare sige, at dét, der ligger mig rigtigt meget på sinde, det er, at vi fremadrettet fører en fornuftig økonomisk politik. Og det er så også det, vi gør. Vi fører en meget offensiv økonomisk politik. Det sætter sig så helt konkret i, at vi noeste år får et betydeligt underskud, der svarer til noget, der ligner fem procent af bruttonationalproduktet. Når vi kan gøre det og samtidig gør det forsvarligt, så hænger det præcis sammen med det forhold, at vi op til det her tidspunkt har ført en overordnet set fornuftig økonomisk politik, hvor vi har brugt de gode år til at gnave af på gælden, nedbragt den offentlige nettogæld, sådan at vi nu forsvarligt også kan øge den i en periode. Det rokker ikke ved, at vi står over for et saet betydelige udfordringer. Vi kan jo glæde os over, at det i den grad ser ud til at lysne $i$ økonomien. Jeg hæfter mig ved, at der lige er kommet nye detailhandelstal, der viser en stigning på det sidste. Lad os håbe, det er et signal om, at noget optimisme er ved at vende tilbage til vores samfund. Det rokker ikke ved, at krisen ikke er ovre. Vi vil se arbejdsløsheden fortsat stige en periode endnu. Og der vil selvfølgelig blive brug for, at vi - kan man sige - konsoliderer den økonomiske politik, fordi det er ikke, kan man sige, langtidsholdbart at køre med underskud af den dimension, vi kommer til at køre med noeste år.

Journalisten beder i sit spørgsmål Løkke om at forholde sig til nationalbankdirektørens kritik af regeringens økonomiske politik i perioden 2004-2007, men Løkke forskyder i sit svar fokus i retning af de økonomiske fremtidsudsigter. Bortset fra en enkelt sætning - gemt af vejen midt i det relativt lange svar - forholder Løkke sig ikke til det, der spørges om, nemlig fortidens økonomiske politik, men svarer i stedet ved at fokusere 'fremadrettet' på de økonomiske prognoser for 'næste år'. Ordene 'fremadrettet' og 'næste år' fungerer således som tidsforskydningsmarkører. Men også den dominerende brug af verbernes nutids- og fremtidsformer, hvor spørgsmålet lægger op til et svar i datid, afslører tidsforskydningen.

Med afsæt i et fremtidsperspektiv bliver det muligt for Løkke at 
fokusere på resultaterne af den 'fornuftige' og 'offensive' økonomiske politik, som regeringen aktuelt fører. Ved at udskifte journalistens kritiske fortidsperspektiv og i stedet lade fremtidsperspektivet være det dominerende i sit svar, kan Løkke altså belyse andre, mere gunstige sider af sagen end dem, journalisten lægger op til, at han skal forholde sig til.

Et andet eksempel på en tidsforskydning finder vi i pressemødet fra den 15. december 2009, hvor COP15-mødet er et tilbagevendende tema. I dette eksempel sker forskydningen fra nutid til fortid, og delvist også fra nutid til fremtid:

Spørger: Nu var der som tidligere nævnt en række afrikanske ledere, der udeblev fra forhandlingerne $i$ går. Der har været en del kritik af det danske formandskab af COP15-mødet. Er det en kritik, der kommer bag på dig?

Statsministeren: Det er jo svært præcist at sige, hvad der kommer bag på mig, og hvad der ikke kommer bag på mig - al den stund at vi jo ikke før har afviklet et møde af den karakter. Det kommer ikke bag på mig, at der er meget støj i kulisserne - det kommer ikke bag på mig. Jeg ved med mig selv, at vi i vores forberedelse af det her - det gælder den tidligere klima- og energiminister nu altså COP15-ministeren, som i regi af det, der hedder Grønlandsdialogen, har lagt mange krcefter $i$ at være i direkte dialog med sine kolleger på en meget balanceret måde. Og det gælder også mig selv, som har brugt mange krcefter på at bygge det her Copenhagen Commitment Circle op med en balance, der sikrer, at både u- og ilande er repræsenteret. Og i øvrigt også ved deltagelse $i$ en rcekke møder - altså senest Commonwealth-mødet i Trinidad, hvor 53 lande var til stede, herunder en række af de allermest udsatte - bl.a. de lande, der er samlet i den gruppe, der hedder AOSIS - altså de små østater - jo brugt utroligt mange kræfter på - med afsæt i neutralitet - at være i dialog med alle. Og jeg ved med mig selv, at det betyder, at Connie Hedegaard har et godt, personligt, tillidsfuldt forhold til en række af de her aktører, og jeg ved også med mig selv, at det samme har jeg. Og derfor kan jeg ikke rigtigt tillade mig at blive meget forstyrret af, at der så er en masse støj i kulisserne. Det afgørende er nu, at nu må vi kaste alle vores krcefter ind $i$ at få de her meget modstridende synspunkter bøjet af mod hinanden, og det tror jeg fortsat godt på vil 
kunne lade sig gøre - i hvert fald på en god dag. Og jeg håber, der opstår en sådan god dag på fredag.

Journalisten lægger i sit spørgsmål op til, at Løkke skal forholde sig til kritikken af det igangværende klimatopmødes afvikling (nutidsperspektiv). Løkkes svar er imidlertid centreret omkring, hvad han og Connie Hedegaard har gjort for at forberede COP15 (fortidsperspektiv). Hovedparten af svaret går således med at redegøre for handlinger, der er gået forud for topmødet: Hvor 'mange kræfter' de har brugt på at være 'i dialog med alle', deltage 'i en række møder', opbygge omfattende og repræsentative netværk og skabe 'personlige tillidsforhold'. I spørgsmålets sidste del anlægger han dog et fremtidsperspektiv, idet han retter blikket frem mod topmødets kommende dage. Begge tidsforskydninger betyder, at han undgår at forholde sig til den kritik, der er rettet mod det danske formandskab og hans indsats som leder af topmødet her og nu, og i stedet kan bruge sit svar på at fremlægge de grundige forberedelser og udtrykke optimisme for de kommende forhandlinger. Et fokus, der stiller ham i et langt bedre lys end det, spørgsmålet lægger op til.

Begge eksempler illustrerer, hvordan Løkke tilsyneladende accepterer spørgsmålet, idet han fastholder emnet for journalistens spørgsmål (økonomisk politik og klimatopmøde). Ved at udskifte journalistens tidsperspektiv med et mere fordelagtigt perspektiv formår han imidlertid at navigere uden om det kritiske punkt i journalistens spørgsmål uden ligefrem at afvise spørgsmålet. Det kan derfor umiddelbart se ud, som om Løkke besvarer spørgsmålet, fordi han jo faktisk holder sig til emnet, men reelt har han drejet journalistens spørgsmål. En opmærksomhed på det tidsperspektiv, der anlægges i Løkkes svar, kan derfor være nyttigt, når man skal vurdere, om han taler udenom.

\section{Aktørforskydning: 'I øjeblikket ser vi en opposition, som kører videre i sædvanlig overbudsstil'}

Ud over tid kan også den eller de aktører, der er impliceret i journalistens spørgsmål, benyttes som afsæt for en forskydning. Den næste form for forskydning, vi skal se på, er derfor det, vi kalder 'aktørforskydning'. 
Aktørforskydningen består i, at Løkke besvarer et spørgsmål, der er møntet på en bestemt person, rolle eller gruppe, ved at tage afsæt i en anden person, rolle eller gruppe. Det sker eksempelvis ved, at han besvarer spørgsmål, der er rettet til ham som person, ved at tage afsæt i en anden og større aktørgruppe, såsom Venstre, regeringen eller Danmark som nation. Denne form for aktørforskydning indebærer, at Løkke i sit svar udvider aktøren. Aktørforskydningen kan imidlertid også virke den anden vej, altså ved at Løkke i sit svar indskrcenker aktøren. Det er f.eks. tilfældet, når Løkke vælger at svare som privatperson, borger eller forælder på spørgsmål, der er rettet til ham som statsminister. Ved hjælp af aktørforskydningen kan Løkke altså bevæge sig mellem de mange forskellige roller, han spiller: privatperson, borger, medlem af Venstre, statsminister, dansker.

Et illustrativt eksempel på en aktørforskydning finder vi i pressemødet fra den 9. februar 2010, hvor kritik af Løkkes lederskab er et tilbagevendende tema. Her foretager Løkke flere forskellige aktørforskydninger i samme svar: Fra regeringsleder til opposition, til Danmark, danskerne og regeringen:

Spørger: $\mathrm{Nu}$ taler du om konvergensprogrammet som den næste politiske dagsorden. Men hvordan vil du sikre på de interne linjer, at du kan stoppe den bl.a. anonyme kritik, der har været af dit lederskab?

Statsministeren: Jamen altså prøv at høre - konvergensprogrammet er ikke sådan det næste politiske projekt eller noget sådant. Konvergensprogrammet, det er en politisk udfordring, som bliver klarlagt, og som bliver det punkt, hvorom den politiske debat i Danmark bliver nødt til at dreje sig de kommende måneder, det kommende år. I øjeblikket ser vi en opposition, som jo kører videre i sådan sædvanlig overbudsstil, som om at krisen aldrig har fundet sted, man kan betale sig fra alting. Det er ikke længere den økonomiske situation i Danmark. Vi er udfordret af lande, der løber meget hurtigere end os. Vi er udfordret af, at $v i$ har truffet en række offensive beslutninger, som har skullet give danskerne tillid og optimisme igen. Det skal der ryddes op i. Og den udfordring, den vil åbenbare sig i sit fulde omfang sidst i denne uge eller først i uge 8, og så er det vores opgave at give de politiske svar på, hvordan vi håndterer det. Det bliver regeringens opgave, 
det bliver også oppositionens opgave. Fribilletternes tid er forbi. Og det svarer sådan set også på det andet spørgsmål, fordi at det er sådan set det, der skal skabe fokus i den politiske debat. Herunder også i det politiske arbejde - både i regeringen og i regeringspartierne.

Journalistens spørgsmål er rettet mod Løkke selv, idet journalisten vil have ham til at forholde sig til sin rolle internt $i$ regeringen. I sit svar forskyder Løkke imidlertid aktøren fra individ til kollektiv ved at fokusere på de økonomiske udfordringer, som Danmark står overfor, og hvad regeringen har truffet af 'offensive beslutninger' for at håndtere krisen og give danskerne 'tillid og optimisme igen'. Ved at ændre og udvide aktøren undgår Løkke altså at forholde sig til den kritik, der er rettet specifikt mod ham i egenskab af regeringsleder, idet han erstatter de udfordringer, han står over for, med nationens udfordringer. Og inden for denne ramme bliver det vigtigere at fokusere på det, der kan samle nationen om den fælles, ydre fjende - den økonomiske krise - end på regeringsintern splittelse. Ligesom han kan få det til at fremstå, som om det er oppositionen og ikke ham, der er problemet, fordi de med deres 'sædvanlige overbudsstil' negligerer krisen. I stedet for at svare på den kritik, der er tilfaldet ham i egenskab af regeringsleder, placerer han altså ansvaret på oppositionen.

Aktørforskydningerne afsløres tydeligt i pronomenbrugen, hvor han ikke en eneste gang i sit svar benytter pronomenet 'jeg', sådan som spørgsmålet ellers lægger op til, men konsekvent taler ud fra et kollektivt 'vi', der implicerer henholdsvis danskerne og regeringen. 'Vi' og 'vores' fungerer derfor i denne sammenhæng som aktørforskydningsmarkører.

Et andet eksempel på en aktørforskydning finder vi i pressemødet fra den 20. oktober, hvor temaet er den forestående klimaaftale. Her forskyder Løkke den ansvarlige aktør fra regeringen til de industrialiserede lande:

Spørger: Bare lige for at konkretisere en af de ting, du taler om - målsætningen for en klimaaftale, hvor du siger, at 2 gradersmålsætningen skal nås med store reduktioner, betyder det, at regeringen stadig arbejder for reduktioner på 25-40 \% i 2020. 
Statsministeren: Ja, det er dét, som gemmer sig i det, man kunne kalde logikken. Altså ... og det er jo derfor, det med 2 gradersmålsætningen er så helt afgørende, fordi hvis man kan fastslå, kan man sige, global konsensus om, at det er målsætningen, så ... nu får jeg det til at lyde for enkelt - men så giver det næsten sig selv, hvad der så skal gøres, fordi så skal de industrialiserede lande reducere i omegnen af dét, du der antyder, det er udfordringen.

Her spørger journalisten specifikt til den danske regerings klimamålsætninger. I Løkkes svar er den ansvarlige aktør dog udvidet til de industrialiserede lande - altså en forskydning fra lokal til global politik. Med henvisningen til 'global konsensus' undgår Løkke at levere det konkrete og forpligtende politiske udspil, som journalisten efterspørger, og som han og regeringen efterfølgende vil kunne holdes op på. Også her gælder det, at forskydningen alene implicerer en ændring i perspektiv (fra det forpligtende regeringsperspektiv til det mere uforpligtende internationale perspektiv), mens spørgsmålets emne (klimapolitik) fastholdes.

Eksemplerne skulle gerne illustrere styrken ved at være opmærksom på aktørperspektivet i Løkkes svar på tirsdagspressemøderne. Hvem er det, der taler? Er det privatpersonen Løkke, Venstre-politikeren Løkke eller statsministeren Løkke? Eller er det regeringen, Danmark eller det internationale samfund? Ved i sit svar at tage afsæt i en anden aktør end den, journalistens spørgsmål er rettet mod, bliver det nemlig i mange tilfælde muligt for Løkke at ændre, hvem der er i fokus, og dermed forskyde ansvaret væk fra sig selv eller den gruppe, han repræsenterer.

\section{Niveauforskydning: 'Det, sagen egentlig handler om'}

Vi har ovenfor set, hvordan både tid og aktør kan benyttes som afsæt for en forskydning af journalistens spørgsmål. Materialet fremviser dog endnu en måde, hvorpå dette gøres, nemlig det, vi vælger at kalde, niveauforskydning. ${ }^{3}$

I en niveauforskydning ændres perspektivet ved, at Løkke enten flytter diskussionen til en mere abstrakt eller en mere konkret ramme. Den mest almindelige variant af niveauforskydning består i, at Løkke besvarer et kritisk spørgsmål i relation til en 
konkret sag ved at fokusere på det abstrakte, bagvedliggende, ideologiske motiv. Niveauforskydningen kan dog også bestå i en bevægelse den anden vej, altså fra det abstrakte til det konkrete, hvor spørgsmål, der vedrører regeringens eller Venstres generelle udmeldinger, i Løkkes svar forskydes til at omhandle konkrete sager eller handlinger. Begge former for niveauforskydning indebærer - på samme måde som med tids- og aktørforskydningen - at han ændrer præmissen for journalistens spørgsmål.

Et klart eksempel på en niveauforskydning finder vi i pressemødet den 1. december, hvor der spørges til Rigsrevisorens kritik af Løkkes økonomiske disponeringer som sundhedsminister. Løkke forskyder her fokus fra konkret sag til ideologi:

Spørger: Jeg vil godt skifte emne totalt fra det internationale til det nationale. Rigsrevisionen har fornyet sin kritik af dig fra dengang, du var sundhedsminister, og gentaget, at du i Rigsrevisionens øjne ikke har begået noget ulovligt, men har ødslet omkring 900 mio. kr. voek. Er du blevet klar over, at Rigsrevisionen har fat i den lange ende?

Statsministeren: Jeg er helt bekendt med, at Rigsrevisor har afleveret et notat til Statsrevisorerne. Det er i øvrigt et led i en helt almindelig proces. Altså forholdet er jo det, at der lå et udspil fra Rigsrevisor, som Statsrevisorerne har behandlet. Regeringen har afgivet sine svar. Rigsrevisor har afleveret et notat til Statsrevisorerne, og de afgiver så på et tidspunkt en betænkning. Og så vil jeg tro, at så genopfører vi formentlig lejligheden til at sige meget om den sag ved den lejlighed. Men når du nu spørger, så kan jeg da godt sætte nogle ord på, fordi hvad er det egentlig, sagen handler om? Sagen handler om, at da vi kom til i 2001, da lagde vi et nyt spor ud for dansk sundhedspolitik, hvor vi valgte at satte patienten først. Vi var trætte af et sundhedssystem, der forskelsbehandlede folk, hvor man, hvis man havde friværdi eller en privat sygeforsikring, så kunne man komme hurtigt i behandling. Havde man ikke det, så kunne man bare stå i kø. Privathospitaler var også dengang opfundet, men de var forbeholdt dem, der kunne betale. Sådan et $A$ - og B-samfund ønskede vi ikke, og derfor så gennemførte vi en meget unik patientrettighed, som betød, at hvis ikke det offentlige kunne behandle inden for to måneder, så kunne patienten søge ud privat. Det er så en patientrettighed, 
vi senere har forbedret, sådan at man nu kan søge privatbehandling efter en måned. For at sætte lidt proportioner på, så har det været sådan, at mens den ordning har kørt, og den er i øvrigt nu under ombygning, der har vi brugt noget, der ligner 3,5 mia. kr. på private sygehuse. Det står i forhold til, at vi i den samme periode har brugt 270 mia. kr. på det offentlige sundhedsvæsen. Så det er altså omkring $1 \%$, der er kanaliseret ud privat. Det siger sig selv, at i takt med at de penge er kanaliseret ud privat og har underbygget en privat sygehusstruktur, så opstår der også en mulighed for at få priserne ned. Og det, diskussionen jo i virkeligheden går på, det er det skifte fra at have et offentligt monopolsygehusvasen til at have et system, der satter patienten i centrum - har den voeret for høj? Det mener vi ikke i regeringen, det mener Rigsrevisor, det må jeg jo tage til efterretning, han mener. Jeg synes ikke, hans argumenter er så stærke. Han bruger selv formuleringen, at der er forskellige indikationer på, at man kunne have fået en lavere pris.

Journalistens spørgsmål tager her afsæt i den konkrete kritik for overbetaling af privathospitalerne, som Rigsrevisionen har fremsat. I sit svar drejer Løkke imidlertid fokus fra væk fra den konkrete økonomiske kritik og fokuserer i stedet på de bagvedliggende ideologiske bevaggrunde for de økonomiske disponeringer. Med afsæt i ideologisk ladede ord som 'forskelsbehandling', 'patientrettigheder', 'A- og B-samfund' og 'offentligt monopolsygehusvæsen' foretager han en forskydning fra en konkret sag om overforbrug til at være en ideologisk sag om rettigheder og principper - altså fra (problematisk) effekt til (prisværdigt) motiv. I denne optik kan (over)forbruget sættes i en højere sags tjeneste og dermed forsvares principielt ud fra den betragtning, at det koster at sikre lighed og rettigheder.

Niveauforskydningen afsløres meget tydeligt i formuleringerne 'Sagen handler om' og 'Det, diskussionen jo i virkeligheden går på'. Disse er sproglige markeringer af, at Løkke eksplicit forsøger at redefinere sagens essens, hvorfor de i denne sammenhæng kan siges at fungere som niveauforskydningsmarkører.

Det er i øvrigt værd at bemærke, at niveauforskydningen i eksemplet understøttes af en aktørforskydning. Hvor journalistens spørgsmål nemlig er rettet til ham i egenskab af tidligere 
sundhedsminister, tager Løkke i sit svar afsæt i, hvad der var regeringens politik. Denne forskydning fra minister til borgerligt kollektiv understreger den ideologiske prægning af sagen, idet det dermed betones, at det interessante ikke er, hvad en enkelt minister har foretaget af økonomiske prioriteringer, men hvordan disse prioriteringer er udtryk for borgerlig værdipolitik.

Et andet illustrativt eksempel på en niveauforskydning finder vi i pressemødet fra den 20. oktober 2009. Her foretager Løkke en forskydning den anden vej, altså fra ideologi til konkret sag:

Spørger: I forhold til den økonomiske krise, kan du så ligesom din politiske ordfører garantere en plads på livets solside, hvis man bare arbejder hårdt nok?

Statsministeren: Jamen, du kan ikke stille spørgsmålet på den måde, fordi jeg har ikke nogen politisk ordfører, der har udstukket en sådan garanti.

Spørger: Så du stiller ikke nogen garanti for, at man kan ...

Statsministeren: ... for hvad?

Spørger: ... for at man kan få en plads på livets solside, bare man arbejder hårdt nok.

Statsministeren: Jamen, jeg tror, at du bevidst eller ubevidst, det kan jeg jo ikke lige gennemskue, men jeg kunne have en eller anden ide om det, altså fejlrefererer den politiske ordfører fra Venstre, som sagde noget om, hvad er det for et samfund, vi ønsker os, og hvad for nogle værdier skal det være bygget på? Og det skal være bygget på den værdi, at man, uanset hvilke omstændigheder man er født under, så skal man have et sæt muligheder, som gør, at hvis man selv kæmper for at få uddannelse, så får man også et godt liv. Men det rokker jo ikke ved, at der så er en krise, og at der aktuelt er en udfordring med f.eks. som ung at finde job på det danske arbejdsmarked. Dét, man kan bebrejde os for, det er, hvis ikke vi agerer på det. Og derfor agerer vi også på det. Meget, meget målrettet med en mia. til ekstra praktikpladser. Med en meget, meget målrettet indsats $i$ forhold til de 15-17-årige, som er i risikozonen, hvis ikke de kommer ordentligt videre fra folkeskolen og ind i videre uddannelse. Det er dét, der er samfundets bidrag. Og inden for den ramme, så er det derfor jo ved siden af også en udfordring for den enkelte unge, og sådan skal det også være. 
Spørgeren henviser med sine spørgsmål til, at Venstres politiske ordfører, Peter Christensen, i sin tale til Folketingets åbning 2009 sagde, at "Alle kan regne med en plads på livets solside, hvis de arbejder hårdt, passer deres pligter, svarer enhver sit og opfører sig ordentligt”. Dette er en generel, ideologisk udmelding, der vedrører almen samfundsmæssig pligtopfyldenhed. I sit svar forskyder Løkke dog fokus i retning af en konkret arbejdsmarkeds- og uddannelsespolitisk diskussion, der vedrører de unge. I stedet for at forholde sig til Christensens generelle værdipolitiske udsagn - eller eksplicit afvise at forholde sig til det - indplacerer Løkke udtalelsen i en realpolitisk ramme, hvor fokus er den aktuelle 'krise', de unges udfordringer med at finde 'job på det danske arbejdsmarked', arbejdet med at skaffe 'praktikpladser' og gøre en 'målrettet indsats i forhold til de 15-17-årige'. Ved at opregne konkrete, realpolitiske udfordringer og tiltag tager Løkke luften ud af det ideologiske udsagn og minimerer dermed eventuelle uenigheder mellem sig selv og sin ordfører.

Hvor tidsforskydningen er et forsøg på at ændre præmissen for, hvornår sagen foregår, og aktørforskydningen for, hvem der har ansvaret for sagen, er niveauforskydningen altså et forsøg på at ændre præmissen for, hvad sagen handler om. Ved at henvise til de prisværdige, bagvedliggende, ideologiske motiver i forhold til konkrete sager kan Løkke undgå at forholde sig til konkrete problematikker, som kan stille ham og regeringen i et dårligt lys ligesom han kan bløde for kontante ideologiske udmeldinger op ved at reducere dem til konkrete realpolitiske problemstillinger.

\section{Afrunding}

Beskrivelsen af de tre former for forskydning skulle gerne belyse det forhold, at man i en journalistisk kontekst skal være lige så opmærksom på spørgsmålsforskydninger som på spørgsmålsafvisninger. Fælles for de tre forskydninger, som vi ser Løkke benytte på sine tirsdagspressemøder, er netop, at de ikke indebærer en afvisning, men en redefinering af journalistens spørgsmål, idet Løkke ændrer det perspektiv eller den præmis, der ligger til grund for spørgsmålet. Det betyder, at forskydningen er en langt mere subtil undvigemanøvre end afvisningen, da 
det kan være svært at gennemskue, hvori omskrivningen af det stillede spørgsmål præcist består. Som journalist kan det derfor også være vanskeligt ikke at blive forført af Løkkes forskydninger og i situationen holde ham fast på den oprindelige præmis i eventuelle opfølgende spørgsmål. Ud over at sætte fokus på den grundlæggende forskel mellem at afvise og forskyde et spørgsmål er det derfor tanken, at den her opstillede typologi over Løkkes forskydninger på tirsdagspressemøderne kan fungere som et praktisk journalistisk redskab. Kataloget over forskydninger skulle således gerne gøre det lettere for journalisten at opdage, når Løkke i sit svar tager afsæt i en anden tid, aktør eller niveau end det, der spørges til.

Selv om det katalog, vi her har opstillet, i udgangspunktet binder på en specifik person - Lars Løkke Rasmussen - i en specifik situation - de ugentlige pressemøder, har de tre forskydninger mere almen gyldighed. Vi fører ganske vist ikke dokumentation for denne påstand, men har observeret, hvordan de tre forskydninger kan genfindes mere bredt i de situationer, hvor en person stilles kritiske journalistiske spørgsmål. Analyserede man et større og mere mangfoldigt spørgsmål/svar-materiale, ville andre typer af forskydninger givetvis dukke op, samtidig med at de tre, vi her har udpeget, sandsynligvis også ville kunne genfindes. De tre her beskrevne forskydninger kan derfor benyttes som inspiration uden for den snævre kontekst, hvorfra de er udsondret, ligesom de kan benyttes som afsæt til at katalogisere andre typer af forskydninger.

JONAS GABRIELSEN, ph.d., Lektor, Institut for Kommunikation, Virksomhed og Informationsteknologier, Roskilde Universitet, jonasg@ruc.dk

HEIDI JØNCH-CLAUSEN, ph.d.-stipendiat, Center for Journalistik, Institut for Sprog og Kommunikation, Syddansk Universitet, hjc@language.sdu.dk

CHRISTINA PONTOPPIDAN, cand.mag., Ekstern Lektor, Institut for Medier, Erkendelse og Formidling, Københavns Universitet, christinapontoppidan@yahoo.dk 


\section{LITTERATURLISTE}

Bull, Peter \& Mayer, Kate (1993): “How Not to Answer Questions in Political Interviews", Political Psychology,Vol. 14, No. 4, s. 651-666.

Bull, Peter (2003): The Microanalysis of Political Communication. Claptrap and Ambiguity. London: Routledge.

Cicero, M. (1993): Topica. Cambridge, Massachusetts: Harvard University Press.

Clayman, Steven \& Heritage, John (2002): The News Interview. Journalists and PublicFigures on the Air. Cambridge: University Press.

Frandsen, Finn (2004): "Spindoktorerne - en episode i det moderne demokratis historie?” I: Nielsen, Mie Femø (red.): Spin, selvfremstilling og samfund - public relations som reflekterende praksis. Frederiksberg: Samfundslitteratur.

Gaber, Ivor (1999): “Government by spin: an analysis of the process", Contemporary Politics, Vol. 5, No. 3, s. 263-275.

Gabrielsen, Jonas (2008): Topik. Ekskursioner i retorikkens toposlaere. Åstorp: Sverige. Retorikforlaget.

Gabrielsen, Jonas (2009): ”Topisk kritik”. I: Marie Lund Klujeff \& Hanne Roer (red.): Retorikkens aktualitet. Grundbog i retorisk kritik, 2. udg. København: Hans Reitzels Forlag, s.141-165.

Gabrielsen, Jonas \& Nørholm Just, Sine (2009): "Boligstoffet: Salgsretorik og forførende tal”. I: Anker Brink Lund, Ida Willing \& Mark BlachØrsten (red.): Hvor kommer nyhederne fra? Den journalistiske fødekade i Danmark før og nu. Århus: Forlaget Ajour, s. 133-142.

Hesselager, Øjvind (2009): "Løkke saboterer kritik”, Journalisten.dk, 16. december 2009.

Højsgaard, Lasse (2010): "Qvortrup tror ikke på spin-fri statsminister", Journalisten.dk, 2. marts 2010.

Jamieson, Kathleen Hall (1992): Packaging the Presidency. A History and Criticism of Presidential Campaign Advertising. Oxford: Oxford University Press.

Jones, Nicholas (1996): Soundbites \& Spin Doctors. How Politicians Manipulate the Media - and Vice Versa. London: Indigo.

Jønsson, Rasmus (2007): "Spindoktorerne på vej”. I: Buchhave, Brit, Høybye, Anne, Lund, Martin og Wagner, Signe (red.): Politisk Spin. København: Akademisk Forlag, s. 92-99.

Jønsson, Rasmus \& Larsen, Ole (2002): Professionel politisk kommunikation. Et studie af 20 dages valgkamp. København: Akademisk Forlag. Jønch-Clausen, Heidi, Pontoppidan, Christina \& Gabrielsen, Jonas 
(2010): "Tirsdagsspin: Løkkes retoriske undvigelser", Politiken, 11. maj 2010, s. 8.

Kock, Christian (2011): De svarer ikke. Fordummende uskikke i den politiske debat. København: Gyldendal.

Lilleker, G. Darran \& Negrine, Ralph (2002): “The Professionalization of Political Communication”, European Journal of Communication, Vol. 73, No. 3.

Nielsen, Mie Femø (red.) (2004): Spin, selvfremstilling og samfund-public relations som reflekterende praksis. Frederiksberg: Samfundslitteratur.

Nielsen, Mie Femø (2009): "En sproglig vinkel på politisk spin”. Dansk Noter, Dansklærerforeningen, Vol. December, nummer 4, s. 16-26.

Nielsen, Mie Femø \& Kock, Christian (2007a): "Hvad er spin?” I: Buchhave, Brit, Høybye, Anne, Lund, Martin \& Wagner, Signe (red.): Politisk Spin. København: Akademisk Forlag, s. 19-35.

Nielsen, Mie Femø \& Kock, Christian (2007b): ”Fire grundlæggende funktionstyper af spin”. I: Buchhave, Brit, Høybye, Anne, Lund, Martin og Wagner, Signe (red.): Politisk Spin. København: Akademisk Forlag, s. 36-62.

Pontoppidan, Christina \& Gabrielsen, Jonas (2009): ”Topik - debattens skjulte niveau", RetorikMagasinet, nr. 74, s. 20-24.

Pontoppidan, Christina, Gabrielsen, Jonas og Jønch-Clausen, Heidi (2010): "Topik. Et retorisk bidrag til den kritiske journalistik", Nordicom Information, Årgang 32, nr. 1, s. 47-59.

Press, Bill (2001): Spin this! All the Ways We Don't Tell the Truth. New York: Pocket Books.

Qvortrup, Henrik (red.) (2002): Exit Nyrup. Tvoersnit af folketingsvalget 2001. København: Høst og Søn.

Scammel, Margaret (1995): Designer Politics. How Elections are Won. New York: St. Martins Press Inc.

Schopenhauer, Arthur (2008): Kunsten altid at få ret. København: Informations Forlag.

www.dr.dk. (2008, d. 8.marts): "Stor vækst i antallet af spindoktorer": http://www.dr.dk/Nyheder/Politik/2008/03/08/230744.htm?rss=true

1 Om end vi her søger at indfange en specifik mekanisme, nemlig forskydninger i spørgsmål/svar-seancer, er selve koblingen af spin og tidsrammer ikke ny. Press taler eksempelvis om "Blame it on my youth"-spin, hvor politikeren imødegår kritikpunkter ved at hen- 
vise til sin ungdom (Press, 2001, s. 10), mens Nielsen og Kock under hovedkategorien "syltekrukkespin" opererer med kategorien "Tid og sted-spin" (Nielsen og Kock, 2007b, s. 49).

2 Også her nærmer vi os en kategori af spin, som vi genfinder i litteraturen. Press taler eksempelvis om "The vast conspiracy spin”, hvor skylden skydes på nogle andre (Press, 2001, s.11), mens Nielsen og Kock blandt andet taler om "jeg-spin”, hvor politikeren skifter mellem sit "jeg" og sit parti eller regeringsgrundlaget (Nielsen og Kock, 2007b, s. 48$)$.

3 Også her kan der peges på paralleller til den etablerede litteratur. Schopenhauer behandlede eksempelvis allerede i 1831 en form for niveauforskydning, idet han taler om "udvidelse" (Schopenhauer, 2008, §1). Gabers kategori "Firebreaking” søger at fastholde det forhold, at man kan ændre fokus i en sag alene ved at opdele sagen i mindre enheder (Gaber, 1999, s. 269). Nielsen og Kock er inde på en lignende tanke i deres kategori "elastikspin", hvor feltet enten kan udvides eller indskrænkes (Nielsen og Kock, 2007b, s. 55). En beslægtet tanke udfolder de med deres "Konsekvens \& intention-spin": Hvis man anklages for, at ens politik har skadelige konsekvenser, kan man undgå at tale om disse konsekvenser ved i stedet at tale om intentionerne bag den (Nielsen og Kock, 2007b, s. 53). Endelig kan det nævnes, at Bull med sin kategori "politisering" kommer tæt på det, vi her kalder en niveauforskydning (Bull 2003, s. 114 ff.) 